\title{
The Relationship between Lifestyle and Hypertension Cases at UPT Cibiru Public Health Center Bandung City
}

\author{
Agung Sutriyawan*, Reni Apriyani, Tenike Gita Miranda \\ Public Health Study Program, Universitas Bhakti Kencana, Bandung, Indonesia \\ ${ }^{*}$ corresponding author, e-mail: agung.epid@gmail.com
}

Received: 02/07/2020; published: 02/04/2021

\begin{abstract}
Background: Hypertension is one of the non-communicable diseases which is the main cause of death in Indonesia (25.8\%). Hypertension is also often called a silent killer because most of the hypertension cases do not cause symptoms. Hypertension is closely related to behavior and lifestyle. Hypertension control is done with behavioral changes, such as conducting adequate physical activity, healthy diet with dietary and quitting smoking. This research aims to determine the relationship between lifestyle, which includes physical activity, diet, and smoking behavior, and hypertension cases. Method: This study used quantitative analytic method with cross sectional research design. The population in this study was all patients who visited and were treated at the public clinic as recorded in the registration report at Cibiru Community Health Center (Puskesmas) in June 2019. The samples were 74 respondents, taken by using purposive sampling technique. The data were analyzed by using the chi square test. Results: The results showed that the lifestyles associated with the hypertension cases were physical activity ( $p$ value $=0.022$ ) and smoking behavior ( $p$ value $=0.003$ ). Meanwhile, the diet was not related to the incidence of hypertension ( $p$ value $=0.326$ ). Conclusion: Based on the research result, it can be concluded that physical activity and smoking behavior were proven to be associated with hypertension, while the diet was not proven related to hypertension. It is suggested that the community health center should maximize the NCD Integrated Guidance Post (Posbindu-PTM) and conduct counseling on the importance of physical activities and the danger of smoking in order to improve the health efforts in the work area of Puskesmas Cibiru.
\end{abstract}

Keywords: hypertension; lifestyle; physical activity; diet; smoking behavior

Copyright $@ 2013$ Universitas Ahmad Dahlan. All rights reserved.

\section{Introduction}

Non-Communicable Diseases (NCD) are the main cause of death in the world. According to the World Health Organization (WHO) Estimates, deaths due to NCD will increase by 15\% globally (as many as 44 million deaths) between 2010 and 2030. The regions that will experience the greatest increase of more than $20 \%$ are Africa, Southeast Asia, and Eastern Mediterranean. All deaths due to NCD occurred in people aged less than 60 years, $29 \%$ happened in developing countries while 13\% happened in developed countries [1]. The change of human lifestyle due to urbanization, modernization and globalization has led to an increase in Non-Communicable Diseases (NCD) [2].

Based on WHO data in 2015, it was shown that about 1.13 billion people in the world suffered from hypertension, meaning that 1 in 3 people in the world was diagnosed with hypertension. The number of hypertension sufferers continues to increase every year. It is estimated that, in 2025, there will be 1.5 billion people suffer from hypertension. Not only that, but it is also estimated that 10.44 million people die from the hypertension and its complications every year [3]. Indonesia Basic Health Research or Riset Kesehatan Dasar (Riskesdas) Data in 2018 showed that the prevalence of hypertension in West Java was the second highest of all provinces in Indonesia. It was found that there were cases of 
hypertension $(39.60 \%)$ in a population of $\geq 18$ years, the prevalence of hypertension in women $(36.85 \%)$ was relatively higher than men (31.34\%) [4].

Hypertension or high blood pressure is a persistent pressure increase in arteries, where the systolic blood pressure is $\geq 130 \mathrm{mmHg}$ and the diastolic blood pressure is $\geq 80$ $\mathrm{mmHg}$ [5]. Hypertension is a major risk factor for cardiovascular diseases. If it is not treated properly, hypertension can lead to stroke, heart attack, heart failure, dementia, kidney failure, and vision problems [6]. Hypertension often causes no symptoms; nearly half of all patients are unaware of their disease. Previous studies have shown that a lifestyle such as diet, physical activity [7], and smoking habit could increase blood pressure [8]. Other studies also suggested that the lack of physical activities, being overweight, malnourished, and smoking could be associated with an increased risk of hypertension even in the prediction of early adulthood hypertension in adolescence [9].

According to the Non-Communicable Diseases Prevention and Control, there are two risk factors for hypertension, namely risk factors that cannot be modified (age, sex, and hypertension history), and risk factors that can be modified (obesity, smoking, the lack of physical activities, high-fat diet, excessive salt consumption, dyslipidemia, excessive alcohol consumption, psychosocial and stress) [10]. The risk factors that can be modified are also known as lifestyle. Lifestyle is a pattern of daily behavior that should be carried out by a social group in the community, in accordance with the norms and religion [11]. Unhealthy lifestyle is one of the ten causes of death and disability in the world. Each year, more than two million deaths are caused by the lack of body movements or physical activities so that the unhealthy lifestyle can lead to hypertension caused by food, physical activity, stress, and smoking [12].

Previous studies showed that $22.5 \%$ of people who frequently consumed excessive salt, $18.7 \%$ of people who rarely ate vegetable, $53.3 \%$ of active smokers, and $14.5 \%$ of people who lacked of physical activities suffered from hypertension. Theoretically, people who are not actively engaged in activities tend to have a higher heart rate, which can lead to an increase in blood pressure [13-15].

In 2018, the prevalence of hypertension in Bandung City, based on the blood pressure measurement, was $20.42 \%$ and $64.45 \%$ occurred in women. The Technical Implementation Unit or Unit Pelaksana Teknis (UPT) of the Cibiru Community Health Center is one of the Puskesmas in Bandung in which the prevalence of hypertension is $16.63 \%$ of all people whose blood pressure was checked there [16]. Based on the information from the program holders of the NCD Integrated Guidance Post or Pos Binaan Terpadu-Penyakit Tidak Menular (Posbindu-PTM) in the Community Health Center, the efforts to overcome hypertension cases at Puskesmas Cibiru have been done a lot. However, hypertension cases are still increasing because a lot of people still do not know that they suffer from hypertension and the community lifestyle is not really healthy. For instance, they rarely do sports, eat unhealthy food like high-fat food, eat less fruit and vegetable, and smoke.

Based on the background, it is necessary to conduct research on people's lifestyle such as physical activity, diet and smoking behavior in order to predict how big the risk of lifestyle in influencing hypertension cases is. This study aims to determine the relationship between lifestyle (physical activity, diet, and smoking) and the hypertension cases.

\section{Method}

This qualitative research used a cross sectional research design. The research was conducted in Unit Pelaksana Teknis (UPT) Cibiru Community Health Center. The samples were taken by purposive sampling technique with the inclusion criteria of patients aged $\geq 18$ 50 years, and the exclusion criteria were hypertensive patients with complications. The sample size was calculated based on the One Sample formula in which the calculation result obtained 74 samples. The measurements of blood pressure were carried out twice using a digital sphygmomanometer. In the first measurement, the respondents were asked not to smoke, not to consume caffeine, and not to exercise or do vigorous physical activity for 30 minutes before the blood pressure check. Furthermore, the respondents took a break for 20 30 minutes, and then they were re-checked to ensure that the blood pressure measurement result was valid.

The categories of blood pressure test results were 1) hypertension (if the systolic blood pressure is $\geq 130$ / the diastolic blood pressure is $\geq 80$ ); 2 ) non hypertension (if the 
systolic blood pressure is $<130$ / the diastolic blood pressure is $<80$ ). The physical activity variable was categorized into: 1) poor physical activity, if the respondent only did light physical activities, such as doing household chores (doing laundry with a washing machine, ironing and cooking), light walking at home or office, watching TV, reading, fishing, and others; 2) sufficient physical activity, if the respondent did moderate and heavy physical activities, such as sweeping the yard, mopping, washing clothes, drawing water from a well, gardening, exercising, pedaling a rickshaw, hoeing, and others. The diet variable was categorized into: 1) poor diet, if the respondent consumed excessive sugar or sweet food and did not consume fruit and vegetable; 2) good diet, if the respondent did not consume too much sugar or sweet food and consumed enough fruit and vegetable. Finally, the smoking behavior variable was categorized into: 1 ) heavy smoker (more than 24 cigarettes per day); 2) moderate smoker (11-24 cigarettes per day); 3) light smoker (1-10 cigarettes per day); and 4) nonsmoker. The data were analyzed by using univariate and bivariate analysis. This study used the Chi Square (X2) statistical test with $21^{\text {st }}$ version of SPSS software.

\section{Results and Discussion}

\subsection{Result}

The results of this study showed that most of the 74 respondents were $\geq 45$ years old $(74.3 \%)$, male $(54 \%)$, and went to middle school for their education $(39.2 \%)$. The data also presented patients who suffered from hypertension $(58.1 \%)$, lacked of physical activities $(52.7 \%)$, consumed a poor diet $(33.8 \%)$, and smoked a lot $(23.0 \%)$. The data can be seen in Table 1.

Table 1. Frequency Distribution at UPT Cibiru Community Health Center

\begin{tabular}{lll}
\hline \multicolumn{1}{c}{ Variable } & $\mathbf{n}$ & $\%$ \\
\hline Age & & \\
$\quad \geq 45$ years old & 55 & 74.3 \\
$\quad<45$ years old & 19 & 25.7 \\
Sex $\quad$ & \\
$\quad$ Male & 40 & 54 \\
$\quad$ Female & 34 & 46 \\
Education & & \\
$\quad$ Elementary School & 11 & 14.9 \\
$\quad$ Middle School & 29 & 39.2 \\
$\quad$ High School & 21 & 28.4 \\
$\quad$ College & 13 & 17.5 \\
Hypertension Case & & \\
$\quad$ Hypertension & 43 & 58.1 \\
$\quad$ Non Hypertension & 31 & 41.9 \\
Physical Activity & & \\
$\quad$ Poor & 39 & 52.7 \\
$\quad$ Sufficient & 35 & 47.3 \\
Diet $\quad$ & & \\
$\quad$ Poor & 25 & 33.8 \\
$\quad$ Good & 49 & 66.2 \\
Smoking Behavior & & \\
$\quad$ Heavy Smoker & 17 & 23.0 \\
$\quad$ Moderate Smoker & 20 & 27.0 \\
$\quad$ Light Smoker & 12 & 16.2 \\
$\quad$ Nonsmoker & 25 & 33.8 \\
\hline
\end{tabular}

Based on the research results, lifestyle was significantly associated with hypertension cases through physical activity $(P R=1.675 ; 95 \% \mathrm{Cl}=1.090-2.576 ; p<0.05)$ 
and smoking behavior $(\mathrm{PR}=2.232 ; 95 \% \mathrm{Cl}=1.227 .-4,060 ; \mathrm{p}<0.05)$. The results of the bivariate analysis are presented in Table 2 .

Table 2. The Result of Bivariate Lifestyle Analysis with Hypertension Cases at UPT Cibiru Community Health Center

\begin{tabular}{|c|c|c|c|c|c|c|c|c|}
\hline \multirow{3}{*}{ Lifestyle } & \multicolumn{4}{|c|}{ Hypertension Case } & \multirow{2}{*}{\multicolumn{2}{|c|}{ Total }} & \multirow{3}{*}{$p$-value } & \multirow{3}{*}{$\begin{array}{c}\text { PR } \\
(95 \% \mathrm{Cl})\end{array}$} \\
\hline & \multicolumn{2}{|c|}{ Hypertension } & \multicolumn{2}{|c|}{$\begin{array}{c}\text { Non } \\
\text { Hypertension }\end{array}$} & & & & \\
\hline & $\mathbf{n}$ & $\%$ & $n$ & $\%$ & $\mathbf{n}$ & $\%$ & & \\
\hline Physical Activity & & & & & & & & \\
\hline Poor & 28 & 71.8 & 11 & 28.2 & 39 & 100 & 0.022 & $(1090-2576$ \\
\hline Sufficient & 15 & 42.9 & 20 & 57.1 & 35 & 100 & & \\
\hline Diet & & & & & & & & \\
\hline Poor & 17 & 68.0 & 8 & 32.0 & 25 & 100 & 0.326 & $\begin{array}{l}1.282 \\
(0880-1867)\end{array}$ \\
\hline Good & 26 & 53.1 & 23 & 46.9 & 49 & 100 & & \\
\hline Smoking Behavior & & & & & & & & \\
\hline $\begin{array}{l}\text { Smoker } \\
\text { Nonsmoker }\end{array}$ & 35 & 71.4 & 14 & 28.6 & 49 & 100 & 0.003 & $(1.227-4.060)$ \\
\hline Nonsmoker & 8 & 32.0 & 17 & 68.0 & 25 & 100 & & \\
\hline
\end{tabular}

\subsection{Discussion}

Based on the results above, the prevalence of hypertension was $58.1 \%$ higher than the data available in the Community Health Center. It was because the research was conducted based on the visitation data one month before the actual research. Furthermore, the high incidence of hypertension in this study was due to the fact that the samples taken were mostly over 45 years old.

The results showed that there was a relationship between physical activity and the hypertension cases at Unit Pelaksana Teknis (UPT) Cibiru Community Health Center with a 1.6 times higher risk. It is in line with the previous studies that suggested the relationship between the lack of physical activities and hypertension cases [17]. Hypertension in the elderly people could be prevented by doing physical activity if the condition of their body was still fit. Physical activity must be introduced to the community, especially to the elderly people, in order to do it properly as recommended [18]. Hypertension cases in the respondents who lacked of physical activities were $71.8 \%$. This suggests that poor physical activity can cause a person to experience a blood pressure increase. The physical activity that was mostly done was doing household chores. Only a few respondents did sports, such as jogging and gymnastics. It is recommended that individuals should do physical activity for 30 minutes at least 4-5 times a week. Regular physical activity has been proven to reduce the risk of diabetes, hypertension, and cardiovascular diseases [19].

Physical activity in leisure time can prevent hypertension, whereas physical activity with walking can prevent hypertension in women [20]. Exercise is widely associated with the management of non-communicable diseases, because regular exercise can reduce peripheral resistance which will lower the blood pressure (for hypertension) and train heart muscles to be accustomed to doing harder work in particular conditions. People who are physically passive tend to have a faster heart rate and their heart muscles have to work harder in each contraction; the harder and the more often the heart has to pump, the greater the force pushing on the arteries [21]. Compared to those who are physically active, people who sit frequently are more likely to have hypertension and heart attack physically [22]. In 1993, the American College of Sports Medicine (ACSM) recommended regular aerobic exercises (resistance exercise) at a sufficient dose to prevent the risk of hypertension, by doing proper movements for 30-40 minutes or more, 3-4 days per week. It can lower the blood pressure by as much as $10 \mathrm{mmHg}$ in systolic and diastolic. Not only reducing stress, but regular exercises can also reduce body weight and burn fat in the blood and strengthen the heart muscles [23].

The results of this study showed that diet was not related to the hypertension cases at UPT Cibiru Community Health Center. In accordance with the previous studies, there was no relationship between diet [24], consumption of high-fat food, sweet food [25], and salt [26] with hypertension cases. The finding of no relationship between diet and the hypertension cases was most likely due to the small number of samples, and therefore affecting the results of the statistical tests. However, it was very likely that the hypertension 
cases were caused by a poor diet. Other researchers argued that adjusting the diet continuously was significantly associated with hypertension. The diet should be fruit, vegetable, low-fat dairy products, whole grains, and a diet that is low in saturated fat, sodium, and processed red meat. An increase in one unit of the food can reduce the risk of hypertension [27].

High fiber intake, especially in the form of soluble fiber, is related to the prevention of hypertension. If the fiber intake is low, it can cause obesity which has an impact on increasing blood pressure and degenerative diseases. Consumption of fruit and vegetable has a relationship with the hypertension cases, even potassium also plays a role in creating osmotic and acid-base balance of body fluid and also has the ability to strengthen blood vessel walls [28,29].

This study revealed that smoking behavior was associated with the hypertension cases at UPT Cibiru Community Health Center with a risk of 2.2 times. This finding is in line with the previous studies which suggested that there was an association between smoking and hypertension cases [30,31]. It is also in line with the results of other studies that hypertension cases were more commonly found in smokers than in non smokers [32]. Nevertheless, there are studies that showed different results that smoking did not cause hypertension [33]. The data from this study presented that the hypertension cases in the respondents who smoked were $71.4 \%$. This proves that people who smoke are more at risk of suffering from hypertension.

Smoking $\geq 20$ cigarettes per day is closely related to the increase of blood pressure and left ventricular hypertrophy. The respondent who smoked more than 30 years had 2.98 times greater risk than those who smoked less than 10 years. People who quit smoking have a lower risk of primary hypertension. The advantages of quitting smoking are seen after 5 years [34]. Smoking affects the hypertension cases. The toxic chemicals such as nicotine and carbon monoxide that are inhaled through cigarettes into the bloodstream can damage the endothelial lining of arteries, resulting in atherosclerosis and high blood pressure. In an autopsy study, it was shown that smoking habits were closely related to the presence of terosclerosis in all blood vessels. Smoking in people with high blood pressure increases the risk of damage to arteries [35].

\section{Conclusion}

Lifestyle, physical activity, and smoking behavior were significantly related to the hypertension cases at UPT Cibiru Community Health Center Bandung City. Patients who lacked of physical activities had a 1.6 times greater risk of suffering from hypertension while patients who smoked had a 2.2 times greater risk of suffering from hypertension. It is suggested to examine more deeply about the types of physical activity that can be done to prevent hypertension and to examine the effect of cigarettes types, the duration of smoking, and the number of cigarettes consumed per day on the hypertension cases.

\section{References}

1. Primiyani Y, Masrul M, Hardisman H. Analisis Pelaksanaan Program Pos Pembinaan Terpadu Penyakit Tidak Menular di Kota Solok. J Kesehat Andalas. 2019;8(2):399-406.

2. Yarmaliza, Zakiyuddin. Pencegahan Dini terhadap Penyakit Tidak Menular (PTM) Melalui Germas. J Pengabdi Masy Multidisiplin. 2019;3(2):93-100.

3. Anggreni D, Mail E, Yuliani F. Faktor-Faktor Yang Mempengaruhi Kejadian Hipertesi Pada Lansia di Dusun Tambak Rejo Desa Gayaman Kabupaten Mojokerto. In: Seminar Nasional Seri III. 2019.

4. Kemenkes RI. Hasil Utama Riset Kesehata Dasar (RISKESDAS) Tahun 2018. Litbangkes. Jakarta. 2018.

5. Whelton PK, Carey RM, Aronow WS, Casey Jr DE, Collins KJ, Dennison Himmelfarb C, et al. Guideline for The Prevention, Detection, Evaluation and Management of High Blood Pressure in Adults: A Report of The American College of Cardiology/American Heart Association Task Force on Clinical Practice Guidelines. J Am Coll Cardiol. 2017;71(6):1269-1324.

6. Sukmaningtyas W. Risk Factors of Hypertension in the Elderly. Advances in Health Sciences Research. 2020;20:215-221. 
7. Lestari DR, Rachmawati K. Hubungan Gaya Hidup dengan Kejadian Hipertensi pada Usia Dewasa di Desa Sapala Kecamatan Paminggir Kabupaten Hulu Sungai Utara. Nerspedia J. 2020;2(1):77-86.

8. Sutriyawan A, Anyelir P. Hubungan Perilaku Merokok dengan Kejadian Hipertensi di Puskesmas Neglasari Kota Bandung. Afiasi: J Keseh Masy. 2019;4(3):97-103.

9. Akbarpour S, Khalili D, Zeraati $H$, Mansournia MA. Healthy Lifestyle Behaviors and Control of Hypertension among Adult Hypertensive Patients. SCIENTIFIC REPORTS 2018;1-9.

10. Direktorat Pencegahan dan Pengendalian Penyakit Tidak Menular (P2PTM). Faktor Risiko Penyebab Hipertensi. Kementerian Kesehatan RI. 2019.

11. Roza AA. Hubungan Gaya Hidup dengan Kejadian Hipertensi di Puskesmas Dumai Timur Dumai-Riau. J Kesehat. 2016;7(1):47-52.

12. Buhar ADY, Mahmud NU, Sumiaty S. Hubungan Gaya Hidup terhadap Risiko Hipertensi pada Lansia di Wilayah Kerja Puskesmas Layang Kota Makassar. Wind Public Heal J. 2020;1(3):188-97.

13. Wijaya I, K KRN, Haris H. Hubungan Gaya Hidup dan Pola Makan terhadap Kejadian Hipertensi di Wilayah Kerja Puskesmas Towata Kabupaten Takalar. Media Publ Promosi Kesehat Indones. 2019;2(2):165.

14. Taufiq LOM, Diliyanti S, Taswin, Muriman Y. Hubungan Gaya Hidup dengan Kejadian Hipertensi pada Lansia di Wilayah Kerja Puskesmas Meo-Meo Kota Bau Bau. J Ind Kreat. 2020;4(1):45-56.

15. Harahap RA, Rochadi RK, Sarumpae S. Pengaruh Aktivitas Fisik terhadap Kejadian Hipertensi pada Laki-Laki Dewasa Awal (18-40 Tahun) di Wilayah Puskesmas Bromo Medan Tahun 2017. J Muara Sains, Teknol Kedokt dan IImu Kesehat. 2018;1(2):68-73.

16. Dinas Kesehatan Kota Bandung. Profil Kesehatan Kota Bandung Tahun 2018. Dinas Kesehatan Kota Bandung. 2018.

17. Bhelkar S, Deshpande S, Mankar S, Hiwarkar P. Association between Stress and Hypertension among Adults More Than 30 Years: A Case-Control Study. Natl J Community Med. 2018;9(6):430-433.

18. Miao H, Weng X, Wu X, Deng A, Zhao J, Cai T, et al. Impact of Physical Activity on The Prevalence of Hypertension among The Older Adults in Beijing Communities. Adv Heal Behav. 2019;2(1):41-48.

19. Monica SJ, John S, Madhanagopal R, Monica SJ, John S. Lifestyle Determinants of Hypertension among Female School Teachers. Int. J of Life Scien. 2018;6(1):229-234.

20. Treff $C$, Benseñor IM, Lotufo PA. Leisure-time and commuting physical activity and high blood pressure: the Brazilian Longitudinal Study of Adult Health (ELSA-Brasil). J Hum Hypertens. 2017;31(4):278-83.

21. Nuraini B. Risk factors of hypertension. J Major. 2015;4(5);10-19.

22. Putri SM. Faktor Dominan Pada Tekanan Darah Penderita Hipertensi. J Media Kesehat. 2017;10(1):31-40.

23. Situmorang PR. Faktor-faktor yang berhubungan dengan kejadian hipertensi pada penderita rawat inap di Rumah Sakit Umum Sari Mutiara Medan tahun 2014. J IIm keperawatan imelda. 2015;1(1):71-74.

24. Harun O. Hubungan Pola Makan Dengan Kejadian Hipertensi Pada Pasien Rawat Jalan. J Kesehat Budi Luhur J IImu-IImu Kesehat Masyarakat, Keperawatan, dan Kebidanan. 2019;12(2):164-171.

25. Adriaansz PN, Rottie J, Lolong J. Hubungan Konsumsi Makanan dengan Kejadian Hipertensi pada Lansia di Puskesmas Ranomuut Kota Manado. ejournal Keperawatan (e-Kp). 2016;4(1).

26. Fitriayani $\mathrm{Y}$, Sugiarto $\mathrm{S}$, Wuni $\mathrm{C}$. Faktor yang Berhubungan dengan Kejadian Hipertensi Esensial di Desa Kemingking dalam Kabupaten Muaro Jambi. J Healthc Technol Med. 2020;6(1):449-458.

27. Zafarmand MH, Spanjer M, Nicolaou M, Wijnhoven HAH, van Schaik BDC, Uitterlinden AG, et al. Influence of Dietary Approaches to Stop Hypertension-Type Diet, Known Genetic Variants and Their Interplay on Blood Pressure in Early Childhood. 
Hypertension. 2020;75(1):59-70.

28. Bertalina B, Muliani M. Hubungan Pola Makan, Asupan Makanan dan Obesitas Sentral dengan Hipertensi di Puskesmas Rajabasa Indah Bandar Lampung. J Kesehat. 2016;7(1):34-45.

29. Suryani N, Noviana, Libri O. Hubungan Status Gizi, Aktivitas Fisik, Konsumsi Buah dan Sayur dengan Kejadian Hipertensi di Poliklinik Penyakit dalam RSD Idaman Kota Banjarbaru. Jurnal Kesehat Indones. 2020;10(2):100-107.

30. Singh S, Shankar R, Singh GP. Prevalence and Associated Risk Factors of Hypertension: A Cross-Sectional Study in Urban Varanasi. Int J Hypertens. 2017;2017:110.

31. Liu X, Zhang D, Liu Y, Sun X, Han C, Wang B, et al. Dose-Response Association between Physical Activity and Incident Hypertension: A Systematic Review and MetaAnalysis of Cohort Studies. Hypertension. 2017;69(5):813-820.

32. Siddiqui JA, Zaidi SA, Iqbal J, Qamar N, Adil R, Ahmed A, et al. Smoking and Blood Pressure Levels in Hypertensive Patients: Evaluating The Role of Gender, Age and Hypertension Duration. Int J Res Med Sci. 2019;7(5):1610.

33. Sohn K. Relationship of Smoking to Hypertension in a Developing Country. Glob Heart. 2018;13(4):285-92.

34. Rahmayani ST. Faktor-Faktor Risiko Kejadian Hipertensi Primer pada Usia 20-55 Tahun di Poliklinik Penyakit dalam RSUD 45 Kuningan. J Syntax Idea. 2019;1(4):100-111.

35. Umbas IM, Tuda J, Numansyah M. Hubungan antara Merokok dengan Hipertensi di Puskesmas Kawangkoan. J Keperawatan. 2019;7(1):1-8. 